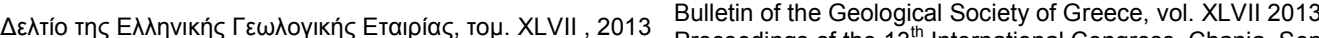
Proceedings of the $13^{\text {th }}$ International Congress, Chania, Sept.

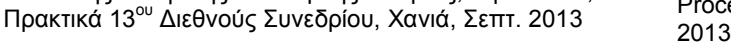

\title{
MINEROLOGICAL AND PHYSICO-CHEMICAL PROPERTIES OF THE BUILDING MATERIALS OF KOULE CASTLE, HERAKLION, CRETE
}

\author{
Karampatsou G. ${ }^{1}$, Markopoulos Th. ${ }^{1}$, Repouskou E. ${ }^{1}$ and Triantafyllou G. ${ }^{1}$ \\ ${ }^{I}$ Technical University of Crete, Dept. of Mineral Resourses Engineering, GR-73100 Chania, \\ Greecegkarampatsou@isc.tuc.gr,markopou@mred.tuc.gr,repusku@mred.tuc.gr, \\ gtriant@mred.tuc.gr
}

\begin{abstract}
This study was designed to determine the physical and technical characteristics of the building stones and mortars of the Koule Castle Heraklion, in order to use compatible materials in future restoration works. Five core samples of rocks and masonry mortars have been extracted from different parts of the monument. Both mortar and rock samples have been studied by optical microscopy and X-ray diffraction (XRD). Their morphological characteristics, granulometry and mineralogical composition have been determined. In the old mortars a thermogravimetric analysis was carried out, while mortar samples have also been studied by scanning electron microscopy. The building stones of Koule Castle are in their majority biomicritic breccia limestones and bioclastic limestones. The binder of the studied mortars consists of calcite, as a result of the lime carbonation. The inert material of the mortars consists mainly of calcite and secondarily of quartz. The inert to binder material ratio was determined by volume from 1/0,96 to 2,6 /1. In conclusion, the mortars to be used in future restoration works, should consist of compatible materials to the old mortars. The inert materials of the mortars should consist of quartz (70\%) and secondarily of calcite (30\%) and the binder of hydraulic lime NHL 3.5, in an inert material/ binder ratio of 2,5/1, in order to protect the mortars against marine corrosion.
\end{abstract}

Key words: Monuments, Building stones, Mortars, Conservation, Crete.

\section{Пєрí $\eta \psi \eta$}

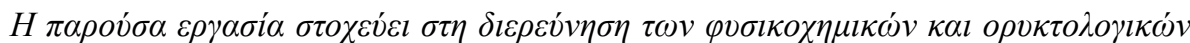

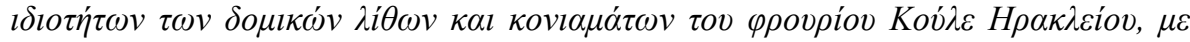

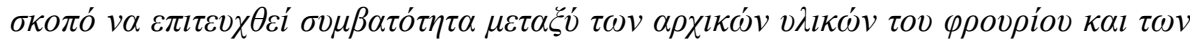

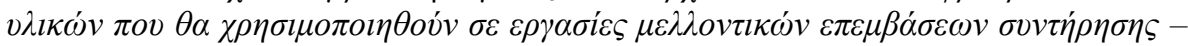

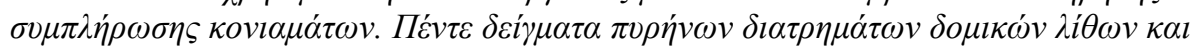

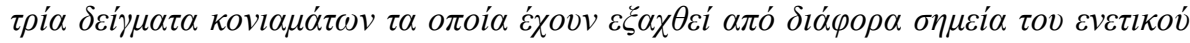

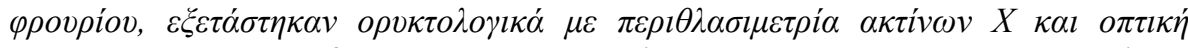

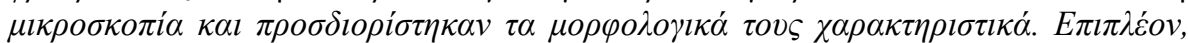

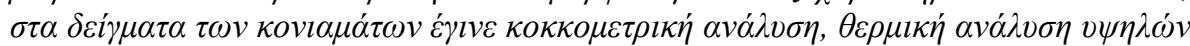

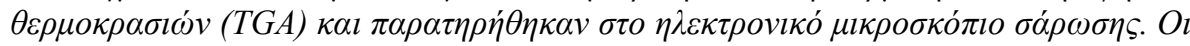

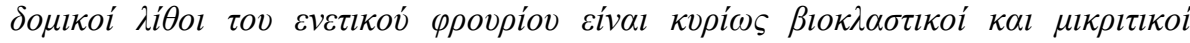

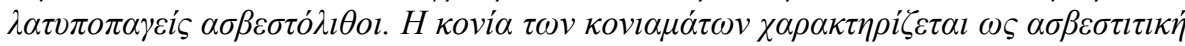

$\underline{\text { XLVII. No } 1-383}$ 


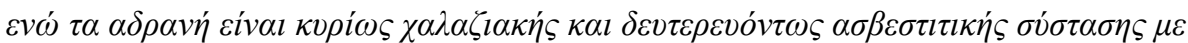

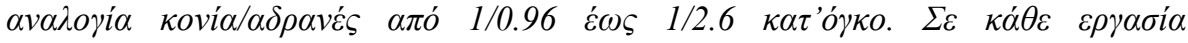

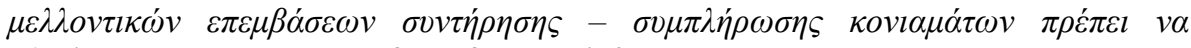

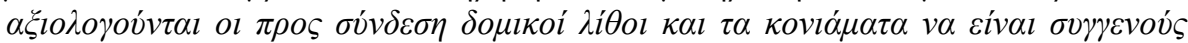

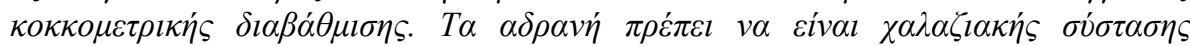

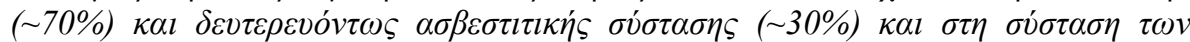

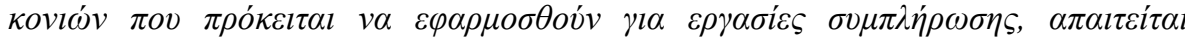

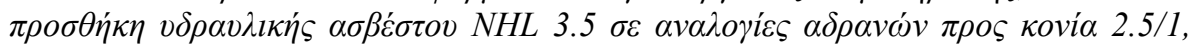

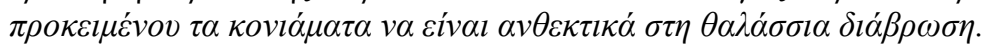

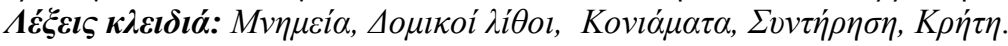

\section{Introduction}

The Koule Castle is an impressive fortress that surrounds the harbor of Heraklion, Crete (Fig.1). The Castle was erected by the Venetians in the early $13^{\text {th }}$ century, when they conquered the town. The Venetians, who were undoubtedly the dominant force of the Mediterranean Sea from the $12^{\text {th }}$ to the $15^{\text {th }}$ century, remained in Crete for about 450 years (1204-1669). During that period of time, Crete becomes the highlight of their conquests and the harbor of Heraklion plays the most significant role for the Venetian trade to the East.

The earliest description of the Koule Venetian Castle exists in the designs of the Florentine monk Christoforo Buondelmonti in 1429. The architecture of the Castle is the typical Venetian architectural style. The construction was such that the walls of the Castle could protect the breakwater of the harbor.

In the early $16^{\text {th }}$ serious damages have been repeatedly presented to the masonry of the fortress due to the force of the waves. The Venetians decided to demolish the Castle and construct a new one, stronger and better fortified against the new war techniques.

According to the floor plan, the new Koule Castle has an extension of about $3600 \mathrm{~m}^{2}$ and an unusual shape compared with other fortification constructions. The Castle consists of two distinct parts: the southwest part featuring a rectangular shape and the southeast part an oval shape. However, the Venetian mechanics had underestimated the force of the Cretan Sea and the Castle remained with broken walls and weak foundations. Hence, the Turks managed to conquer the fortress in 1669 and to obtain the control of the harbor of Heraklion until the late $19^{\text {th }}$ century.

During the Turkish domination time, the Koule Castle maintained its original shape but the Turks constructed a smaller fortress opposite of the Venetian Castle which called it "little Koule Castle". Unfortunately, this monument was demolished in 1936 due to the development of the town.

The aim of the present study is to determine the physical and technical characteristics of the building stones and mortars of the Koule Castle, in order to use compatible materials in future restoration works.

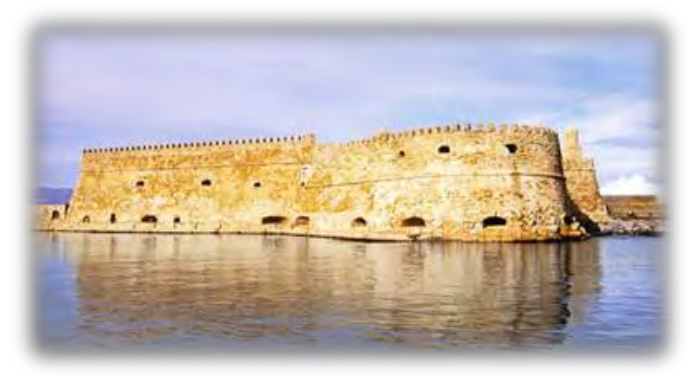

Figure 1 - Koule Castle, Heraklion, Crete.

XLVII. No $1-384$ 


\section{Materials and Methods}

\subsection{Sampling}

Five core samples of rocks and masonry mortars have been extracted by the 13th Municipality of Byzantine Antiquities from different parts of the monument (Table 1). The core samples consist of three rock + mortar specimens and two rock specimens. Various analyses were carried out, in order to determine their physical and technical characteristics as well as well as their deterioration state. The rock specimens present in their majority salt efflorescence (Fig.2) due to the sea water that enters the Castle.

Table 1 - Samples of the building materials of Koule Castle.

\begin{tabular}{|l|l|l|l|l|}
\hline \multicolumn{2}{|c|}{ Location } & $\begin{array}{l}\text { Building } \\
\text { Stones }\end{array}$ & \multicolumn{1}{|c|}{ Sedimentary Rock Types } & $\begin{array}{c}\text { Masonry } \\
\text { Mortars }\end{array}$ \\
\hline \multirow{2}{*}{$\begin{array}{l}\text { Ground } \\
\text { floor }\end{array}$} & Internal wall & $\mathbf{1}$ & bioclastic limestone & B \\
\cline { 2 - 5 } & External wall & $\mathbf{2}$ & micritic breccia limestone & A \\
\hline $\begin{array}{l}\text { Upper } \\
\text { floor }\end{array}$ & Internal wall & $\mathbf{3}$ & bioclastic limestone & C \\
\cline { 3 - 4 } Pavement & $\mathbf{4}$ & micritic conglomerate limestone & \\
\hline
\end{tabular}

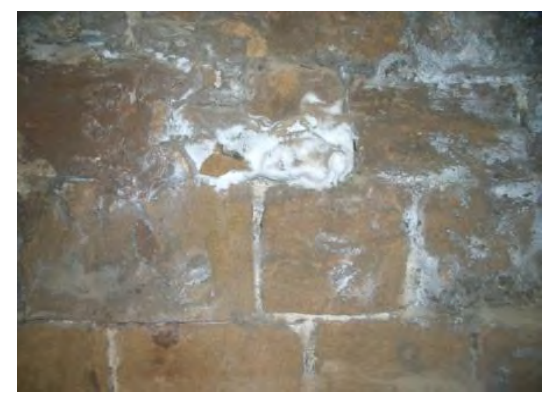

Figure 2 - Salt efflorescence on the external wall of Koule Castle, Heraklion, Crete.

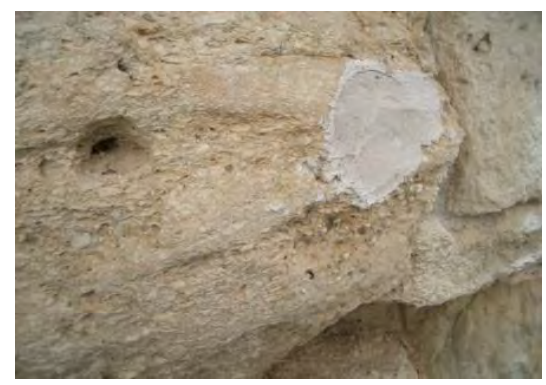

Figure 3 - Sampling position of a building stone from the internal wall of Koule Castle. The drill hole was covered with a non compatible mortar.

\subsection{Mineralogical Analyses}

The mineralogical phases of both mortar and rock samples were identified by X-ray diffraction (XRD) using a BruckerAXS D-8 Advance powder diffractometer with a tube $\mathrm{Cu}$ anode $(35 \mathrm{Kv}$, $35 \mathrm{~mA}$ ). Calcium carbonate was determined by the Dietrich Fruhling gas volumetric method. Loss of ignition was determined by heating to $1050^{\circ} \mathrm{C}$. 


\subsection{Electron Microscopy and EDS Analyses}

The mineralogical phases identified by X-ray diffraction were confirmed by means of a Scanning Electron Microscope. Selected mortar prisms were cut into cubes of approximately $10 \mathrm{~mm}^{3}$ size, one side of which was polished flat. The microstructure and mineralogy of the specimens were studied in a Jeol 5400 scanning electron microscope equipped with an energy dispersion spectrometer (EDS) detector.

\subsection{Thermal Analysis}

The mortars' binder material was examined by thermogravimetric analysis in order to confirm the mineralogical phases identified by the previous analytical techniques and methods. Because of the dynamic character of thermogravimetry, one can distinguish from slope variations the release of $\mathrm{CO}_{2}$ resulting from carbonation, in contrast to that emerging from the natural calcite. TGA analysis was performed at a $10^{\circ} \mathrm{C} / \mathrm{min}$ heating rate from $40^{\circ} \mathrm{C}$ to $910^{\circ} \mathrm{C}$.

\subsection{Grain Size Distribution}

The mortars particle size analysis was carried out by wet sieving, in order to determine the nature of the constituents and evaluate the inert to binder material ratio. The sum of the $2 \mathrm{~mm}-0.125 \mathrm{~mm}$ fractions is regarded as inert material, whereas the material finer than $0.125 \mathrm{~mm}$ is regarded as the binder (Markopoulos et al., 1994).

\subsection{Optical Microscopy}

The rock specimens were investigated in thin sections using optical microscope. Most of the thin sections were cut vertically to the surface of the samples, in order to study the external corrosion and the morphological and mineral properties of the building rocks.

\section{Results and Discussion}

\subsection{Mineralogical Analyses}

\subsubsection{Rock Samples}

The mineralogical phases identified by means of XRD of the rock samples are summarized in Table 2. The building stones of Koule Castle consist mainly of calcite and quartz and the sample 5 mainly of dolomite. The majority of the specimens contain mica and plagioclase while sample 2 contains clinoclhore and sample 1 and 5 contain talc in low quantities.

Table 2 - XRD identification of samples 1,2,3,4 and 5.

\begin{tabular}{|l|l|l|l|l|l|l|l|}
\hline Sample & Calcite & Quartz & Dolomite & Plagioclase & Mica & Talc & Clinochlore \\
\hline 1 & +++ & ++ & - & + & + & + & - \\
\hline 2 & +++ & ++ & - & + & + & - & + \\
\hline 3 & +++ & ++ & - & + & + & - & - \\
\hline 4 & +++ & ++ & - & + & - & - & - \\
\hline 5 & ++ & ++ & +++ & - & - & + & - \\
\hline
\end{tabular}

+++: dominantly present, ++: present, +: present in low quantities, -: not present

The high proportions of $\mathrm{CaCO}_{3}$ and $\mathrm{CaMg}\left(\mathrm{CO}_{3}\right)_{2}$ explain the high loss of ignition values determined of the rock samples (Table 3). Furthermore, the measured content of $\mathrm{CaMg}\left(\mathrm{CO}_{3}\right)_{2}$ in sample 5 confirms the XRD analysis, which indicated the presence of dolomite in the same sample. 
Table 3 - Calcium carbonate (\%), Calcium Magnesium carbonate (\%) and loss of ignition (\%) of the rock samples.

\begin{tabular}{|l|l|l|l|}
\hline Sample & $\begin{array}{c}\mathrm{CaCO}_{3} \\
(\%)\end{array}$ & $\begin{array}{c}\mathrm{CaMg}\left(\mathrm{CO}_{3}\right)_{2} \\
(\%)\end{array}$ & $\begin{array}{c}\text { L.O.I. } \\
\text { (\%) }\end{array}$ \\
\hline 1 & 77.91 & 0 & 34.54 \\
\hline 2 & 71.79 & 0 & 32.33 \\
\hline 3 & 92.45 & 0 & 39.77 \\
\hline 4 & 94.31 & 0 & 38.62 \\
\hline 5 & 9.73 & 73.45 & 38.02 \\
\hline
\end{tabular}

The building stones of Koule Castle are sedimentary rocks, excavated nearby the harbor of Heraklion, where the monument was constructed. In their majority, they are bioclastic limestones with various marine fossils (Fig.4), micritic breccias(Fig.5) and micritic conglomerate limestones. Dolomitic limestones exist only in the pavement of the Castle.

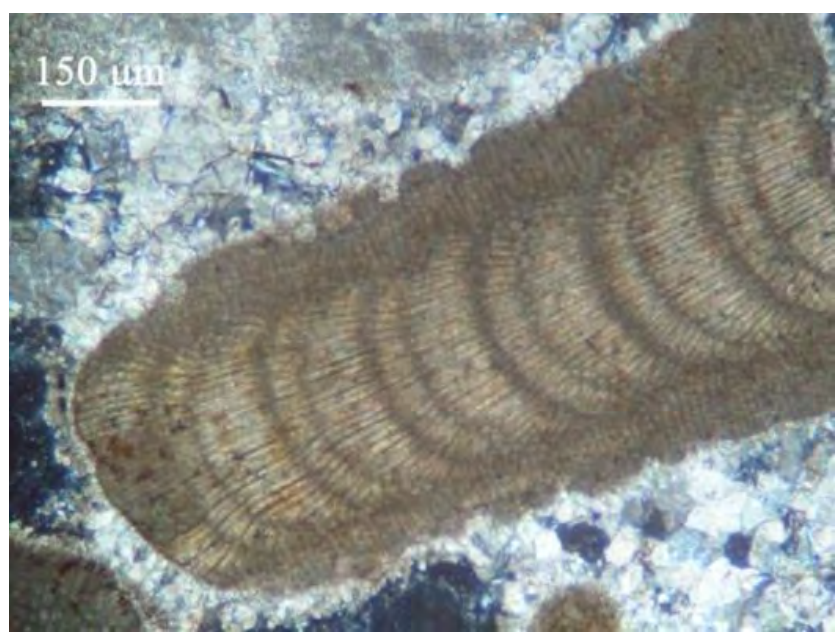

Figure 4 - Thin section photograph of bioclastic limestone. $\perp$ pollars (specimen 1$)$.

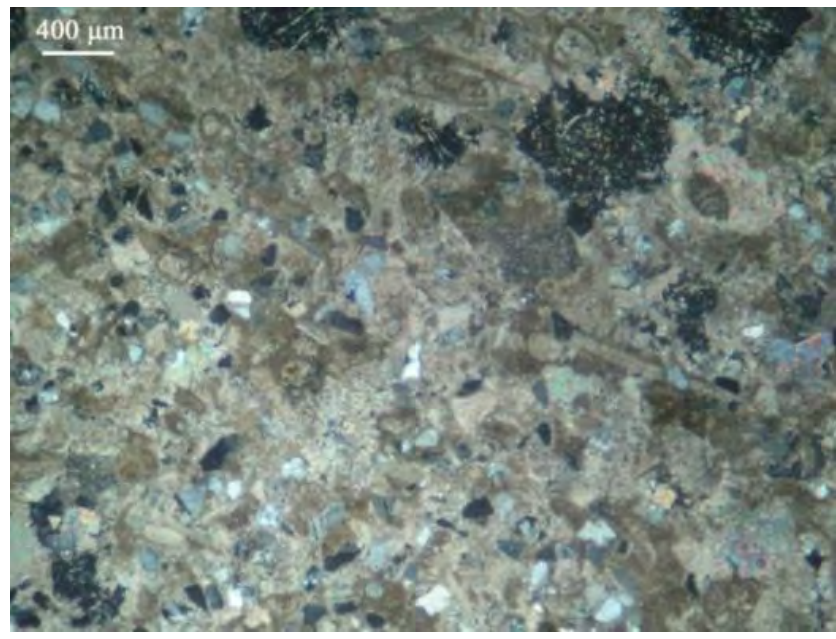

Figure 5 - Thin section photograph of micritic breccia limestone. $\perp^{\perp}$ pollars (specimen 2 ). 


\subsubsection{Mortar Samples}

The mineralogical phases identified by means of XRD of the mortar samples are presented in the XRD patterns below (Figs. 6, 7 and 8).

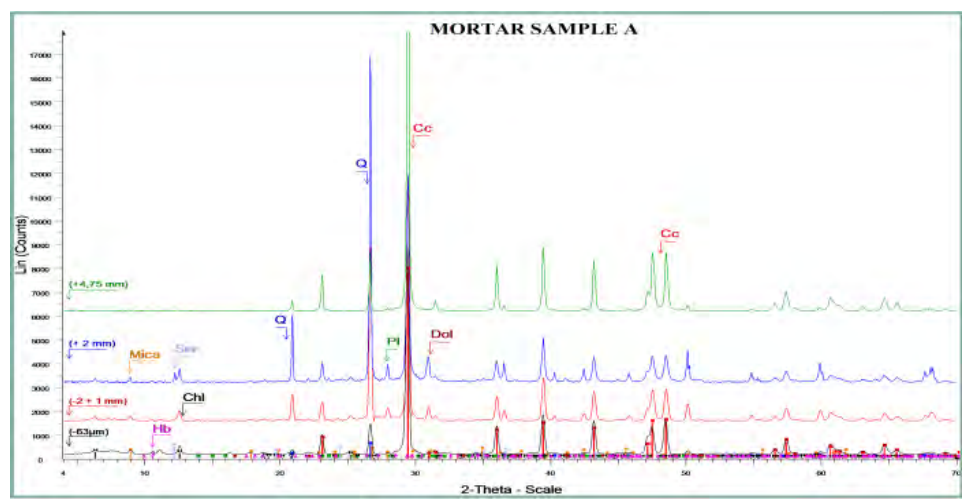

Cc: Calcite, Q: Quartz, Dol: Dolomite, Ser: Serpentine, Chl: Chlorite, Pl: Plagioclase, Hb: Hornblende

Figure 6 - XRD pattern of the binder and inert material of mortar sample A.

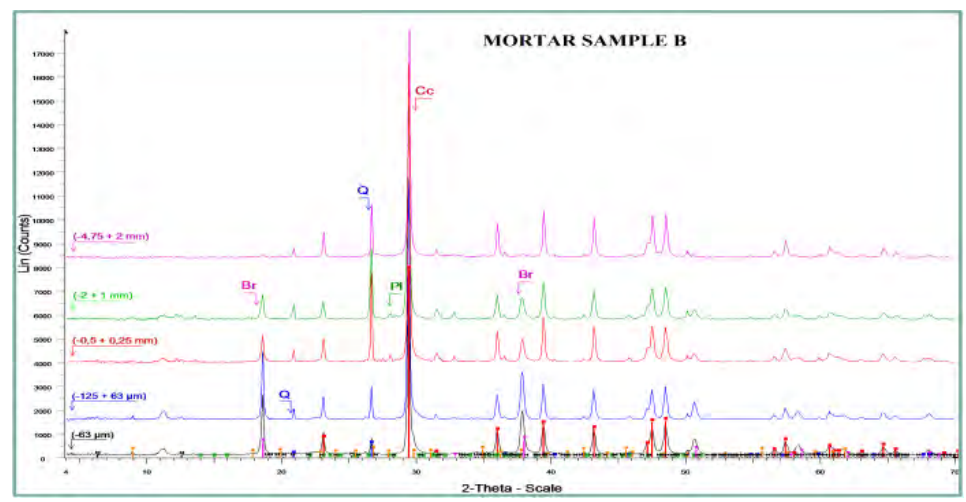

Br: Brucite

Figure 7 - XRD pattern of the binder and inert material of mortar sample B.

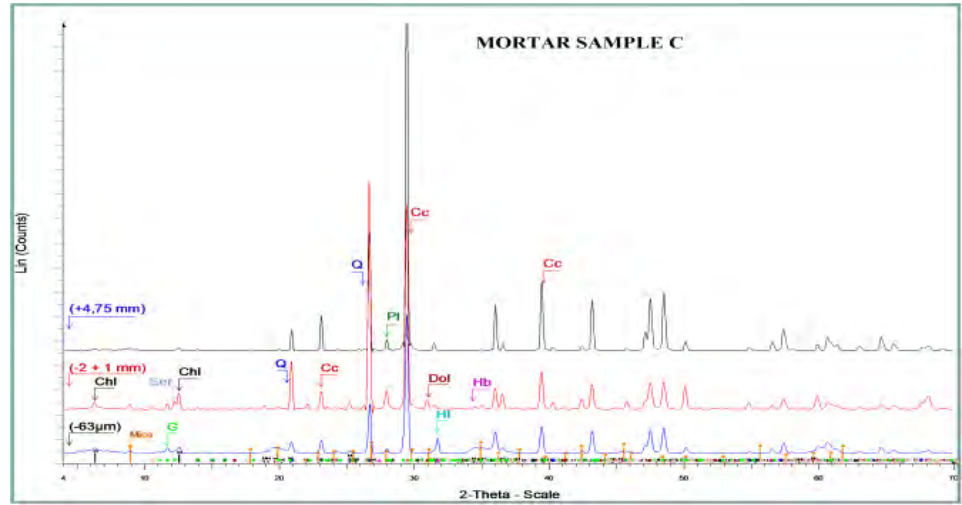

G: Gypsum Hl: Halite

Figure 8 - XRD pattern of the binder and inert material of mortar sample $C$.

$\underline{\text { XLVII, No } 1-388}$ 
Calcite and quartz were detected in the binder and in the inert material of the mortars. The quartz peaks in the XRD spectra are greater for the inert material while the calcite peaks are greater for the binder material of the mortars. Plagioclase, mica, chlorite and hornblende were detected in the binder and in the inert material of mortar samples A and C (Fig. 6, Fig. 8), while dolomite and serpentine exists only in the inert material of these mortars. Plagioclase, brucite and traces of mica and chlorite; were detected in the binder and in the inert material of mortar sample B. Consequently, the binder of the studied mortars consists mainly of calcite as a result of the lime carbonation. The inert material of the mortars consists mainly of quartz and secondarily of calcite. The presence of brucite in sample B (Fig. 7) is probably associated with the absence of adequate carbon dioxide in the interior parts of the castle. Furthermore, the presence of gypsum in sample $\mathrm{C}$ (Fig.8) is attributed to the process of mortar deterioration by sulfating. The sulfates, coming from the marine environment, were deposited on the surface and reacted with $\mathrm{CaCO}_{3}$, present in the mortar, according to Eqs. 1a and 1b. The mechanism of sulfating has not resulted in the formation of ettringite because of the absence of "calcium aluminate hydrate" $\left(3 \mathrm{CaO} \mathrm{Al}_{2} \mathrm{O}_{3} 6 \mathrm{H}_{2} \mathrm{O}\right)$ (Sabbioni et al., 2001).

$$
\begin{aligned}
& \mathrm{CaCO}_{3}+\mathrm{SO}_{2}+0.5 \mathrm{H}_{2} \mathrm{O} \rightarrow \mathrm{CaSO}_{3} \bullet 0.5 \mathrm{H}_{2} \mathrm{O}+\mathrm{CO}_{2}(1 \mathrm{a}) \\
& 2 \mathrm{CaCO}_{3} \bullet 0.5 \mathrm{H}_{2} \mathrm{O}+\mathrm{O}_{2}+3 \mathrm{H}_{2} \mathrm{O} \rightarrow 2 \mathrm{CaSO}_{4} \bullet 2 \mathrm{H}_{2} \mathrm{O}(1 \mathrm{~b})
\end{aligned}
$$

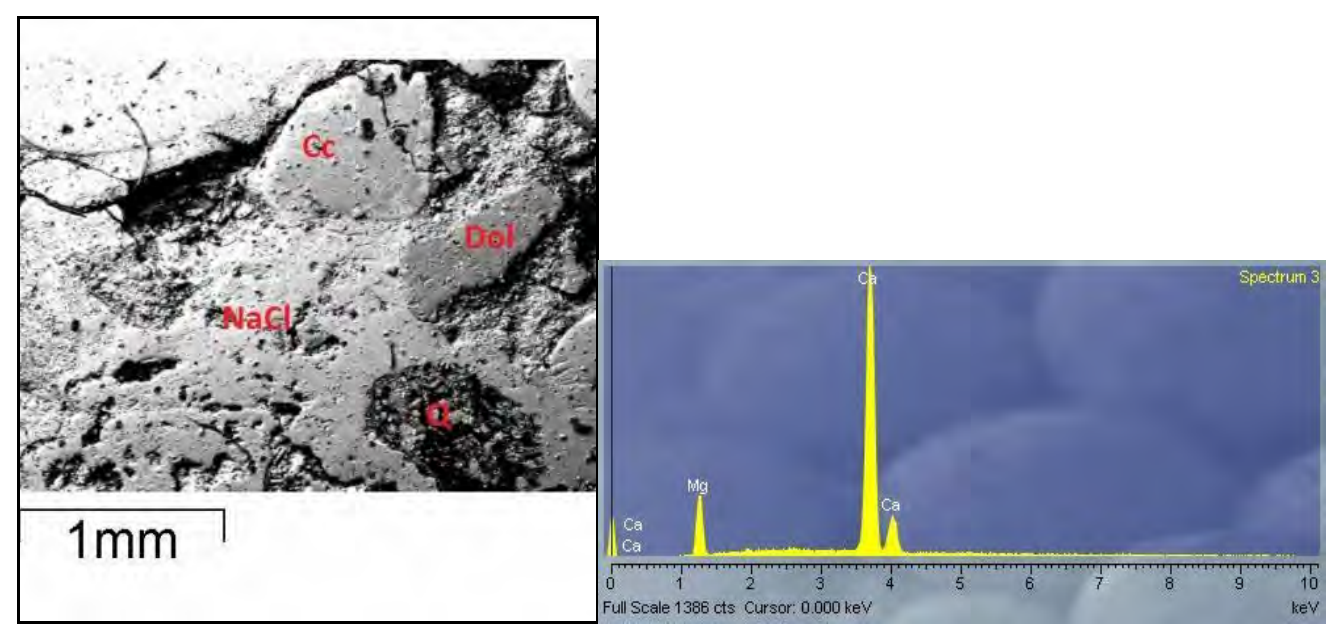

Figure 9 - Backscattering image of the mortar A and EDS analysis of dolomite.

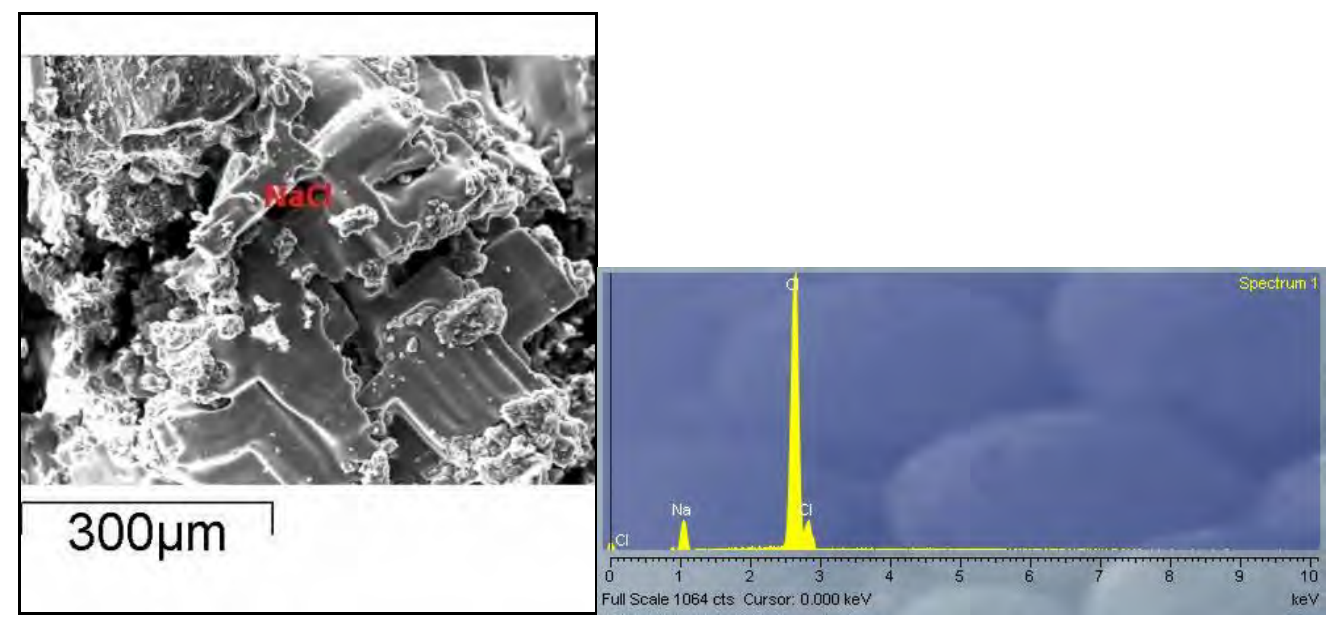

Figure 10 - SEM micrographic of the mortar C and EDS analysis of halite. 


\subsection{Thermal analysis}

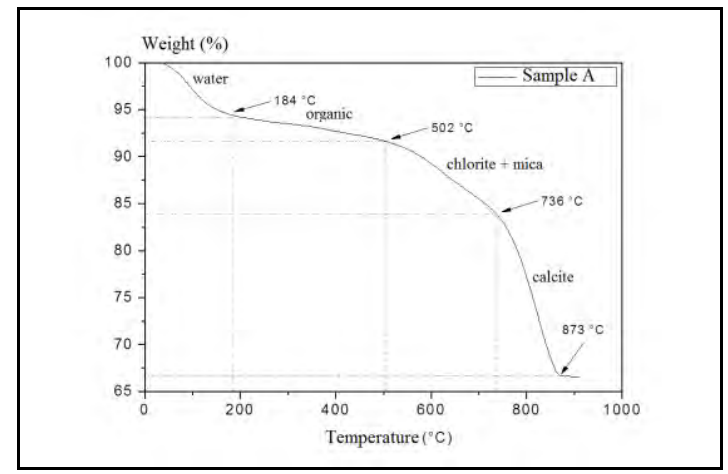

Figure 11 - Thermal curve of sample A.

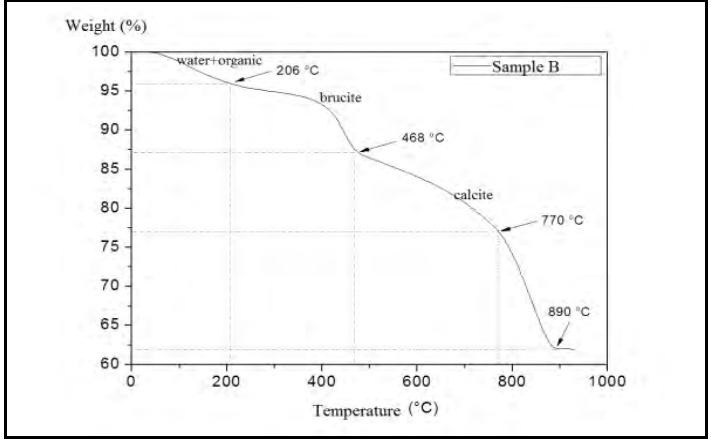

Figure 12 - Thermal curve of sample B.

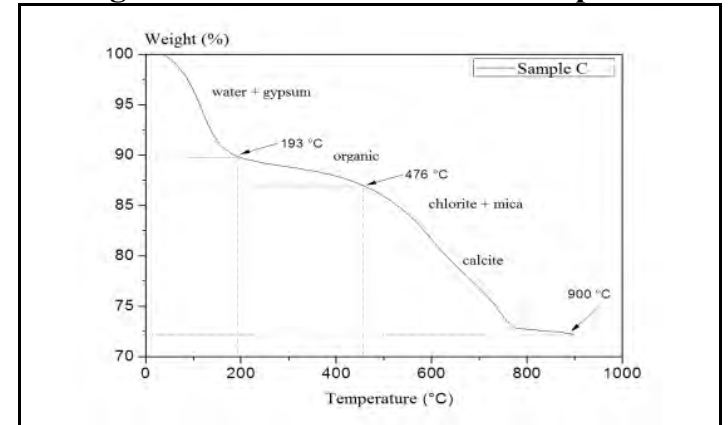

Figure 13 - Thermal curve of sample $C$.

Thermogravimetric (TG) analysis is necessary to establish the characteristics of the ancient mortars. TG analysis indicated a notable effect of calcite decomposition at about $900^{\circ} \mathrm{C}$, as a result of the carbonation of the original lime binder (Figs. 11, 12 and 13). Chlorite and mica decomposition took place at $500{ }^{\circ} \mathrm{C}-600^{\circ} \mathrm{C}$ in the samples $\mathrm{A}$ and $\mathrm{C}$ (Figs. 11 and 13). The losses of mass for the three mortars between $20{ }^{\circ} \mathrm{C}$ and $200{ }^{\circ} \mathrm{C}$ corresponded to the loss of water and to the loss of organic elements later. A greater loss of mass occurred between $20^{\circ} \mathrm{C}$ and $200{ }^{\circ} \mathrm{C}$ in the sample $\mathrm{C}$; which indicates the decomposition of the content gypsum. For the TG curve obtained of sample B, an endothermic peak was observed at about $400{ }^{\circ} \mathrm{C}$ which corresponds to the dissociation of brucite.

\subsection{Grain Size Distribution}

According to the histogram (Fig. 14) sample B presents a normal granulometric distribution. The inert to binder material ratio was determined $1.4 / 1$, by volume. Sample A is the finest of the three studied mortars, due to the fact that more than $50 \%$ of this material is concentrated in the base 
sieve. The inert to binder material ratio for the sample A was determined $0.96 / 1$ by volume. Sample $\mathrm{C}$ contains much more aggregates than the other mortar samples. The inert to binder material ratio for the sample $\mathrm{C}$ was determined $2.6 / 1$ by volume.

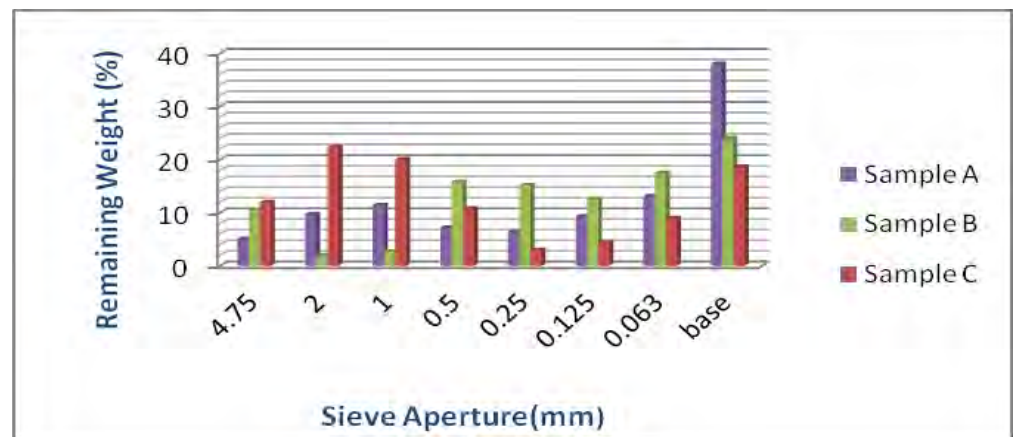

Figure 14 - Weight (\%) of the samples which remains in every sieve aperture.

\section{Conclusions}

The following conclusions can be drawn from the study:

- The building stones of Kule Castle are bioclastic limestones, micritic breccia limestones, micritic conglomerate limestones and dolomitic limestones, excavated nearby the harbor of Heraklion.

- The mineralogical components of the building stones are mainly calcite and quartz and secondarily plagioclase, mica, talc and clinochlore. The dolomitic limestone contains dolomite as the main mineral phase.

- The inert material of the mortars consists mainly of quartz and secondarily of calcite. The inert to binder material was determined by volume from $0.96 / 1$ to $2.6 / 1$. Their examination revealed that beach sand has been used as inert material.

- The presence of brucite in the inert material of mortar B, as well as the presence of dolomite in the inert material of mortar A and mortar C, indicates the use of dolomites or $\mathrm{Mg}$-rich limestones as aggregates. Due to the absence of adequate carbon dioxide, brucite was never converted to magnesium carbonate.

- The binder of the studied mortars consists mainly of calcite as a result of the lime carbonation. The lime used as binder of mortar $\mathrm{A}$ and mortar $\mathrm{C}$ came from bioclastic limestones, while the presence of brucite in the inert material of mortar B indicates that the lime used as binder of this mortar came from dolomites or Mg-rich limestones.

- The mortars to be used in future restoration works, should consist of compatible materials to the old mortars. The inert materials of the mortars should consist of quartz (70\%) and secondarily of calcite (30\%) and the binder of hydraulic lime NHL 3.5, in an inert material/ binder ratio of $2,5 / 1$, in order to protect the mortars against marine corrosion.

\section{References}

Markopoulos Th., Maravelaki P. and Repouskou E. 1994. The materials of the Venetian fortifications in Chania: properties, weathering forms and mechanisms. III Inter. Symp. on the conservation of Monuments in the Mediterranean Basin, Ed. By V. Fassina, H. Ott, F.Zezza. Venice, 22-25 june 1994, 687-692.

Sabbioni C., Zappia G., Riontino C., Blanco -Varela M.T., Aguilera J., Puertas F., Van Balend K. and Toumbakarid E.E. 2001. Atmospheric deterioration of ancient and modern hydraulic mortars, Atm Envon., 539-548. 